\title{
D(i)e verhouding prediking, mus(z)iek en liturgie
}

\begin{tabular}{|c|c|}
\hline \multicolumn{2}{|c|}{$\begin{array}{l}\text { Authors: } \\
\text { Cas Wepener } \\
\text { Mirella Klomp }\end{array}$} \\
\hline \multicolumn{2}{|c|}{$\begin{array}{l}\text { Affiliations: } \\
\text { 1Department of Practical } \\
\text { Theology, Faculty of } \\
\text { Theology, University of } \\
\text { Pretoria, South Africa }\end{array}$} \\
\hline \multicolumn{2}{|c|}{$\begin{array}{l}{ }^{2} \text { Protestantse Theologische } \\
\text { Universiteit, The Netherlands }\end{array}$} \\
\hline \multicolumn{2}{|c|}{$\begin{array}{l}\text { Note: } \\
\text { Cas Wepener is an } \\
\text { associate professor and } \\
\text { Head of the Department } \\
\text { Pratical Theology, Faculty } \\
\text { of Theology, University of } \\
\text { Pretoria, South Africa. He } \\
\text { is a lecturer in Liturgical } \\
\text { Studies and Homiletics. } \\
\text { Mirella Klomp is a Protestant } \\
\text { theologian specialising in } \\
\text { Practical Theology, more } \\
\text { specifically in Ritual Liturgical } \\
\text { Studies. Her research focus } \\
\text { is often on music. She } \\
\text { works as Senior Researcher, } \\
\text { Lecturer in Practical Theology } \\
\text { and Executive Officer of } \\
\text { IRiLiS at the Protestant } \\
\text { Theological University } \\
\text { in Amsterdam. She is a } \\
\text { research associate of Prof. } \\
\text { Wepener in the Department } \\
\text { Practical Theology, Faculty } \\
\text { of Theology, University of } \\
\text { Pretoria }\end{array}$} \\
\hline \multicolumn{2}{|c|}{$\begin{array}{l}\text { Correspondence to: } \\
\text { Cas Wepener }\end{array}$} \\
\hline \multicolumn{2}{|c|}{$\begin{array}{l}\text { Email: } \\
\text { cas.wepener@up.ac.za }\end{array}$} \\
\hline \multicolumn{2}{|c|}{$\begin{array}{l}\text { Postal address: } \\
\text { Private Bag X20, Hatfield } \\
0028 \text {, South Africa }\end{array}$} \\
\hline \multicolumn{2}{|c|}{$\begin{array}{l}\text { Dates: } \\
\text { Received: } 07 \text { Apr. } 2015 \\
\text { Accepted: } 29 \text { Apr. } 2015 \\
\text { Published: } 24 \text { Aug. } 2015\end{array}$} \\
\hline \multicolumn{2}{|l|}{ Read online: } \\
\hline 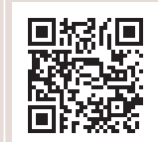 & $\begin{array}{l}\text { Scan this QR } \\
\text { code with your } \\
\text { smart phone or } \\
\text { mobile device } \\
\text { to read online. }\end{array}$ \\
\hline
\end{tabular}

The relationship between preaching, music and liturgy. In the Reformed liturgy in South Africa the sermon has traditionally been reserved a special place, taking precedence over the liturgy and music. In this article an argument is put forward for a better balance between preaching, liturgy and music in the Reformed liturgy in churches in South Africa. In order to do so, the South African Reformed liturgical context is briefly sketched and thereafter a theological and liturgical-historical argument is presented. Existing approaches with regard to the relationship between liturgy, music and preaching by some established scholars are discussed before the implications of the argument are examined in conclusion.

\section{Die Suid-Afrikaanse Gereformeerde konteks met betrekking tot preek, musiek en liturgie}

Wat is die mees algemene opmerking wat voorgangers en erediensgangers hoor na afloop van 'n erediens? Tradisioneel in die Gereformeerde tradisie in Suid-Afrika setel die kommentaar, waarderend of dan juis nie, om die preek. Erediensgangers sal hulle belewenis van die liturgie uitdruk met opmerkings soos 'dit was 'n goeie preek' of "n slegte preek' of 'vandag se preek was vir my bedoel'. In sekere gemeentes sal dit ook goedskiks gebeur dat predikers óf dieper ingevra óf uitgedaag word ten opsigte van die preek wat hulle gelewer het. Op 'n soortgelyke wyse word daar in die Gereformeerde tradisie in Suid-Afrika gedurende die teologiese opleiding van studente van klaspreke en 'n proefpreek gepraat en tradisioneel nié van klaseredienste of 'n proeferediens of proefliturgie nie. In verschillende protestantse tradities in Nederland wordt sinds jaar en dag ook van 'preekconsent' gesproken en is de situatie in dit opzicht vergelijkbaar.

Die klem op die preek of selfs voorrang van die preek ten opsigte van die erediens in die Gereformeerde tradisie in verskeie wêrelddele is alombekend en word gewoon aanvaar as hoe dit nie alleen is nie, maar ook hoe dit behoort te wees. Selde hoor predikante na afloop van die erediens 'n uitdrukking soos: 'Dominee, jy het my vandag werklik gehelp om God te aanbid.' Die taalgebruik van beide predikante en erediensgangers met betrekking tot die preek en liturgie spreek boekdele oor die onderliggende teologiese oortuigings en insgelyks oor die belang van beide liturgie en prediking. In die lig van die ontwikkeling rakende liturgie in die gees van die negentiende en twintigste eeu se Liturgiese Beweging is dit haas tyd dat hierdie stand van sake onder die loep geneem word, te wete om weer na te dink oor óf die onderwaardering van die liturgie óf die oorwaardering van die prediking en nog 'n rondte te dink oor die verhouding tussen die twee en die aksent wat elk behoort te kry. ${ }^{1}$ Dit is presies wat in hierdie artikel beoog word en daaromrede sit 'n Nederlandse en Suid-Afrikaanse liturgis koppe bymekaar om vanuit hulle onderskeie kontekste oor hierdie onderwerp te reflekteer, alhoewel die eksplisiete oogmerk van die artikel is om 'n bydrae in hierdie verband te lewer vir die Suid-Afrikaanse Gereformeerde liturgiese konteks.

Saam met die vraag rakende die verhouding preek en liturgie kan die vraag in ons eie dag ook tereg gevra word na nie alleen die plek van die preek in die liturgie nie, maar ook van musiek in die liturgie. In de eredienst waarin de preek een hoofdrol speelt, wordt soms nogal argeloos omgegaan met psalmen en hymnen: als de boodschap van de preek leidend is voor de coupletkeuze van een lied ('Gemeente, wij zingen nu van Psalm 74 de coupletten 1, 4, 7 en 13') dan is de muziek duidelijk ondergeschikt aan de prediking. Alsof niet de tekst van zo'n psalm of hymne zélf een geheel is - een compositie met een zekere opbouw en onderlinge samenhang 1.Die outeurs is bewus daarvan dat die tema wat hulle aanroer nie' $n$ nuwe tema is nie, maar desnieteenstaande is die diskussie hieroor
verseker nog nie finaal beslis nie. Dit is onses insiens juis nou die tyd dat hierdie tema weer aangeroer word in ons eie spesifieke kulturele en denominasionele kontekste van beide Suid-Afrika en Nederland.

How to cite this article: Wepener, C. \& Klomp, M., 2015, 'D(i)e verhouding prediking, mus(z)iek en liturgie', HTS Teologiese Studies/ Theological Studies 71(3), Art. \#2992, 8 pages. http://dx.doi.org/10.4102/hts.v71i3.2992

Copyright: @ 2015. The Authors. Licensee: AOSIS OpenJournals. This work is licensed under the Creative Commons Attribution License. 
van de verzen - maar een verzameling losse zinnen waaruit het vrij kiezen is. Dit was insiggewend om in 'n hoofstuk van prof. G.M. Pellissier te lees hoedat hy sy ongelukkigheid ten opsigte van die stand van die erediens in sy eie dag in SuidAfrika, meer as sestig jaar gelede, uitdruk. Ons haal Pellissier (1958:144) aan: 'Die prediking het dus alle belangstelling tot hom gesuig en die res van die diens net 'n décor vir homself gemaak.' Op 'n ander plek in die hoofstuk sê hy:

Hoe haas die prediker hom nie soms van die votum tot by die tweede Gesang- of Psalmvers om by die aankondiging van sy teks te kom nie. 'n Aaneengeskakelde geringskatting! Welke sondes van sleurwerk, roetinering en outomatismes tree hier nie in nie! Welk 'n verantwoording voor sy Here! (bl. 144)

Dit wil dus voorkom asof dit ' $\mathrm{n}$ voortdurende roeping is van liturgiste en himnoloë binne die groter Protestantse en spesifiek ook Gereformeerde tradisie om ten minste die aandag op hierdie verhouding te vestig, kritiese vrae in hierdie verband te vra en ook te poog om roetemerkers in hierdie verband aan te stippel in hulle eie dag.

In hierdie artikel word die verhouding preek, musiek en liturgie dus verken en ook wel vanuit 'n verskeidenheid van invalshoeke te wete histories en teologies, en in die proses word 'n argument uitgewerk vir 'n komplimentêre benadering ten opsigte van preek, musiek en liturgie binne die hedendaagse Gereformeerde tradisies in Suid-Afrika en Nederland.

\section{Die hoender of die eier? Bybel of liturgie en musiek?}

'n Vraag wat uit hierdie eerste kort inleidende skets van die Suid-Afrikaanse Gereformeerde liturgiese, himnologiese en homiletiese konteks voortvloei, is wat bepalend is vir of primaat het bo die ander, te wete prediking, liturgie of musiek? Hierdie mag na 'n baie eenvoudige vraag klink wat sommer vinnig beantwoord kan word, te wete dat die Skrif die voorrang moet geniet, bepalend is vir die preek en dat die liturgie en ander elemente soos die musiek gewoon net daar is om die boodskap te dien (Small 2003). ${ }^{2}$ So byvoorbeeld is aanddienste dikwels gesien as preke met Gesang-toebroodjies wat duidelik die voorrang van die prediking bo beide liturgie en musiek verklap. Die vraag na die verhouding preek, liturgie en musiek is egter nie so heel eenvoudig nie en daarom vra dit om kwalifisering en gee ons dus eers een groterige tree terug om weer later terug te kom op hierdie vraag.

Die tree wat ons eers terug wil gee is die vraag na die verhouding prediking en liturgie en daarna ook musiek en liturgie vanuit ' $n$ historiese perspektief en daarvanuit dan ook om te vra watter een van die twee in beide gevalle die vorm van watter een bepaal. Saam daarmee sal iets van die rol van die amp met betrekking tot prediking, liturgie

2.Small lewer'n pleidooi vir'n herwaardering van die sakramente in die Gereformeerd liturgiese tradisie en voer' $n$ argument wat baie nou saamhang met die argument liturgiese tradisie en voer' $n$ argument wat baie nou saamhang met die argument
wat ons hier aanbied. Sien in hierdie verband ook die reeks artikels oor Nagmaal in wat ons hier aanbied. Sien in hierdie verband ook die
die NG Kerk (Burger 2002; Wepener 2002a, 2002b). en musiek ook beter uit die verf kom. Onses insiens kan ons nie 'n pasklare liturgie of liturgieë inklusief musiek uit die Bybel aflei nie, maar het die Bybel wel in die ritme van die feeste, die samekomste, die seisoene - kortom, in die liturgie, ontstaan. Natuurlik kan dit ook net mooi andersom geargumenteer word, te wete dat die liturgie ook saam met die ontstaansgeskiedenis van die Bybel vorm gekry het. So byvoorbeeld ontwikkel die sinagoge-liturgie as oorlewingstrategie van Israel in Babilonië om te kan onthou (White 2000) en later ook die tafel-tradisie as een vorm uit die tyd van die vroeë kerke. Hetzelfde geldt voor muziek: wat gezongen en gespeeld werd in liturgische praktijken heeft deels een plaats gekregen in de Bijbel. Omgekeerd geldt ook dat gezangen in de Bijbel - het boek der Psalmen (dat eigenlijk een liedboek is), Hooglied en Cantica ${ }^{3}$ - de liturgie mede hebben gevormd, en daarin klinken tot op de dag van vandaag. ${ }^{4}$

Ons kernvraag is dus: moet die preek/(teks)(te) die liturgie en musiek bepaal of hoe kan daar oor hierdie verhouding gedink word? Ons glo hierdie vraag help ons ook met die vraag na die plek van die preek in die liturgie en die groter samehang van die geheel van preek, liturgie en musiek. Dit wil voorkom of die verhouding histories komplementêr was, 'n soort én-én resiprositeit tussen teks en liturgies-musikale konteks. En dit is juis dan ook ons uitgangspunt waardeur ons die vraag van die plek van die preek in die liturgie met die musiek benader oftewel die plek van die liturgie en musiek om die preek benader. Ons lyn van argumentasie klink dalk vir sommige lesers nou baie voor die hand liggend, maar dit is gegewe die Gereformeerde liturgiese tradisie eintlik heel radikaal om so daaroor te praat. Hiermee wil ons geensins afbreuk doen aan die plek en belang van die preek in die erediens nie, maar wel net 'n lansie breek dat die liturgie, inklusief die musiek, net soveel klem as die preek behoort te kry en dat die ontwikkeling van die liturgie, musiek en preek ook op 'n komplimentêre wyse moet geskied.

\section{'n Kort geskiedenis}

In het nu volgende deel ondernemen we een historische excurs, eerst ten opzichte van de preekdienst en vervolgens ten opzichte van muziek in de liturgie. Aan de hand van deze historische verkenningen trachten we aan te tonen dat het primaat van de preek bóven liturgie en muziek als benadering in de voorreformatorische liturgie niet bekend is.

\section{Die preekdiens}

Hierdie historiese ekskurs ten opsigte van die sogenaamde pronaus (voor die tempel) oftewel preekdiens as deel van die liturgie bring iets in beeld van die wederkerigheid tussen preek en liturgie deur die eeue. Die aksent word hier op veral

3.Cantica: aan de Schrift ontleende lofliederen zoals bijvoorbeeld het lied van Mozes en van Mirjam (Ex 15) en de lofzangen van Hanna (1 Sam 2), Debora (Richt 5), Simeon (Luc 2), Zacharias (Luc 1) en Maria (Luc 1).

4.In de vieringen van de gebedsgetijden hebben drie kantieken een vaste plaats gekregen. In het ochtendgebed (de lauden) is dat de lofzang van Zacharias (het Benedictus), in de vespers de lofzang van Maria (het Magnificat) en in de completen aan het eind van de dag de lofzang van Simeon (het Nunc dimittis). 
twee aspekte gelê, te wete die plek van die prediking in die liturgie asook die rol van die amp (priester/predikant) met betrekking tot liturgie, musiek en prediking. Ons begin met die ontstaan van die sinagogediens tydens die Babiloniese ballingskap.

Oorspronklik het die sinagogediens 'n nasionalistiese funksie (White 2000:152) wat soos reeds genoem gemik was op die oorlewing van Israel in Babilonië. Die verhale is gelees en die dade van God met Israel in herinnering geroep. Psalm 137:4 se tragiese vraag: 'Hoe kan ons die lied van die Here sing in 'n vreemde land?' moes beantwoord word en die liturgiese antwoord was die sinagogediens wat grotendeels 'n woorddiens was. Die resultaat was 'n diens wat iewers tussen aanbidding en lering geplaas kan word. ' $n$ Ander voorbeeld in hierdie verband is natuurlik die diens in Nehemia 8 wat bestaan uit lesings en oordenkings van die lesings. Hugh Old (2002:60-61) wys juis ten opsigte van Nehemia en die oorsprong van die diens van die woord hoe die amp tydens die ballingskap verander het en priesters daar predikers geword het. In Lukas 4 kan heelwat hiervan waargeneem word, te wete die lesings uit beide die wet en die profete en die oordenking (prediking) van die tekste as uitleg en toepassing met teologies gesproke 'n spesifieke mens as kern van beide die prediking en aanbidding. Wat ons hier beredeneer is nie ' $n$ eenvoudige kontinuïteit tussen die Joodse en Christelike liturgiese tradisies nie, maar eerder dat die aksent op die rol van die amp met betrekking tot liturgie en prediking deur die eeue gewissel het. Priester wie se primêre liturgiese taak die kultus was, het mettertyd verskuif na 'n primêre klem op die prediking. Hierdie soort ossilasie rakende die klem betreffende die primêre take van die amp van die priester/predikant/pastoor is ook in die loop van 2000 jaar se liturgiegeskiedenis waarneembaar en is belangrik rakende die betoog wat in hierdie artikel gevoer word. (Liturgie)historici se menings verskil ten opsigte van die presiese ontwikkelinge met betrekking tot die woorddiens en tafeldiens en daaromrede word meerdere kenners se menings hier gelug.

Een andere visie is dat er geen parallellen moeten worden gesuggereerd tussen synagogale liturgie en dienst van de Schrift/Woorddienst enerzijds en tussen de sacramentele cultus van de Jeruzalemse tempel en dienst van de Tafel/ Anaphora/eucharistie anderszijds (Boon 1970:4-5, voetnoot 4). Aan de eucharistieviering zou aanvankelijk een samenzijn vooraf gegaan zijn, waarin onder meer plaats zou zijn ingeruimd voor een verkondiging uit de Schriften. Dit samenzijn zou echter van het geheel van de eucharistieviering een onderdeel hebben gevormd. De vroegchristelijke liturgie mag volgens deze interpretatie dus niet worden gepresenteerd als samensmelting van twee oorspronkelijk los van elkaar staande typen samenkomsten (met essentiële verschillen in karakter en herkomst): het gaat veeleer om een onderscheid tussen twee momenten binnen het kader van één liturgische viering. Volgens deze zienswijze ontstonden vroeg-christelijke liturgische praktijken uit een combinatie van oudere tradities en liturgische elementen. Hoe dan ook: er was volgens deze opvatting geen sprake van een tweedeling tussen de verkondiging van het woord en de 'rest' van de liturgische viering. Daarmee is in ieder geval duidelijk gemaakt dat in de voorreformatorische liturgie elk accent op of primaat van de prediking ontbrak. Deze laatste bewering wordt ondersteund door de liturgische verantwoordelijkheid van de bisschop: vanuit zijn ambt fungeert hij in de vroege kerk bij de tafelviering (de anaphora) als priesterlijke pater familias van de gemeente als huisgezin van God. In het voorafgaande deel van de viering (de proanaphora) heeft hij vooral een leidende rol en gaat hij zelf (slechts) voor in een enkel gebed en de predikatie (Boon 1970:218-219). Gezien vanuit de primaire taken van het priesterambt staan Schrift/Woord en Tafel/eucharistie in deze periode duidelijk op gelijke voet.

Ons slaan hier groot historiese dele oor, aangesien ons spesifieke interesse lê ten opsigte van die verhouding preek en liturgie asook die rol van die amp in hierdie opsig en daarom lig ons slegs enkele sake eksemplaries uit. Met die ontwikkeling van die tafelgemeenskap in die Nuwe Testamentiese tyd en na die uitbanning van die Christene uit die sinagoges vind 'n fusie van sinagogediens en tafeldiens plaas volgens White (2000:154), wat dus inderdaad 'n ander siening is as die van Boon. Wat hier van belang is, is die komplementêre punte van woord en sakrament as een van die kenmerke van die geskiedenis van die liturgie oor tweeduisend jaar, maar juis ook die reeds vermelde ossilasie met betrekking tot die aksent wat gelê word ten opsigte van die rol van die voorgangers. So byvoorbeeld is die vierde eeu gesien as die goue eeu met betrekking tot prediking en die plek van die woord in die liturgie met predikers soos Chrisostomos, Ambrosius en Augustinus wat nog in die sfeer van die klassieke retorika meesters was in die kuns van prediking (vgl. o.a. Barnard 1998:213-214; Old 2002:64-68). Daar is in hierdie tydperk verseker sprake van 'n ontwikkeling ten opsigte van plek en rol van die tafel of altaar in die liturgie, alhoewel die belang van en klem op die prediking in hierdie periode nie oorgesien moet word nie, veral in die lig van ontwikkelinge in die eeue wat gevolg het.

Gedurende die Middeleeue verskuif hierdie klem op die prediking aansienlik en word die fokus veel meer op die altaar geplaas. In hierdie tyd het prediking minder belangrik geword en in sekere plekke heeltemal verdwyn uit die liturgie. Karel die Grote het dit probeer herstel deur vir die monnik Alcuin te vra om die leesrooster te hersien en 'n preekrooster te skryf wat gebaseer is op die leesrooster (Old 2002:68). In so 'n preekrooster was voorbeeld-preke opgeneem wat maar eenvoudige homilieë was wat deur die priesters gebruik kon word. ${ }^{5}$ Belangrik egter om waar te neem is dat die pendulum met betrekking tot die klem op die rol van die voorganger in

5.Daar was ook'n paar ligpunte rakende prediking in die Middeleeue: Bernardus van Clairvaux het in die elfde eeu gesorg vir die hergeboorte van Christelike prediking. Hy is bekend daarvoor dat hy gepreek het vir die kruisvaarders en ook prediking. Hy is bekend daarvoor dat hy gepreek het vir die kruisvaarders en ook verder vir monnike in kloosters. Bekend is sy ongeveer 80 preke oor Hooglied. Ware verandering rakende prediking kom in die dertiende eeu met Franciscus van Assisi en die Dominikane. Franciscus preek vir die armes en baseer sy boodskappe grotendeels op die Bybel. Soos Franciscus uitstekende preke lewer vir die armes, so preek Dominicus teen allerlei dwaalleringe in sy dag. In die veertiende eeu in Italië, nog voor die aanbreek van die Reformasie, was daar byvoorbeeld 'n man met die naam Bernardino de Siena wat dikwels hele stede tot bekering gebring het deur sy prediking (kyk Old 2002). 
hierdie tydperk verskuif en die aksent val op die liturgie en liturgiese voorgaan met 'n klem op die sakramentsbediening, eerder as op die prediking.

Tydens die Reformasie word die bestaande ellips in die liturgie van woord- en tafeldiens geskei en kan ons dit veral terugvoer na Zwingli, al was dit juis Zwingli se bedoeling dat Gereformeerde Christene meer gereeld aan die tafel aansit as die Rooms Katolieke erediensgangers in sy dag (vgl. Wolterstorff 1992:294). Alhoewel die bedoeling by verskeie reformatore (Zwingli, Luther, Calvyn) eerder 'n dubbele aksent op beide liturgie en prediking was, is die realiteit in die Gereformeerde tradisie (veral Zwingli en Calvyn) dat om verskeie redes die aksent veel eerder op die prediking geval het en as sodanig ook ten koste van die sakramentsbediening. Benamings vir die amp in hierdie tradisie soos Verbi Divini Minister en predikant is ook duidelike aanduidings waar die aksent geplaas is, te wete die prediking, eerder as priester wat sou dui op 'n beklemtoning van die liturgiese voorgaan en diens by die altaar.

Volgens Barnard (1998:212) kan 'n mens die geskiedenis van die preek in die kerkdiens aflees van die plek van die kansel. Beginnende in die eerste eeue na Christus kry ons die Cathedra/thronos waar die biskop sit terwyl hy sy kommentaar op die skriflesing bied. Ons sien iets hiervan in Lukas 4 waar Jesus ook gaan sit om te preek. In 'n later periode word die preek vanaf die ambo ('anabainoo' opklim) gehou wat natuurlik die begin van die preekstoel is voor in die kerkgebou. Hierdie preekstoel of kansel word later in die doksaal, wat die skip en koor van die kerk skei opgeneem gedurende die Middeleeue en langs die altaar met die altaar in die middel, en is die klem en fokus van die erediensgangers dus op die altaar wat sentraal staan. Gedurende die Reformasie skuif die preekstoel na die middel van die liturgiese ruimte en is dit nou sentraal soos wat die altaar sentraal is in die Rooms Katolieke kerke. Die geskiedenis van die prediking tydens die Reformasie is uiteraard 'n komplekse geskiedenis. Belangrik hier is om te sien hoe woord en tafel of altaar hier in die Gereformeerde tradisie grotendeels geskei word, ten dele onbedoeld, maar desnieteenstaande, en verder ook die teologiese aksentuering van die Woord en die Gees wat nooit buiteom die Woord werk nie. Die huidige situasie ten opsigte van die verhouding prediking en liturgie in die Gereformeerde tradisie kan alleenlik in die lig van die Reformasie se klem op die Woord verstaan word.

'n Redelik nuwe ontwikkeling onder invloed van die Liturgiese Beweging is die kombinasie van preekstoel en tafel met óf 'n kommunie-opstelling óf die preekstoel agter die tafel en dus staan beide sentraal. Sodoende word die klem gelê op beide die woordbediening en die sakrament, dus ' $n$ klem op beide preek én liturgie. 'n Verdere tendens is natuurlik om net ' $n$ kateder op ' $n$ verhoog te hê sonder ' $n$ tafel binne die meer Charismatiese tipe dienste en in sommige eredienste is daar ' $n$ herlewing van die gebruik om te sit en preek. Laastens kan genoem word dat daar wêreldwyd Gereformeerde kerke is wat tans weer besin oor die rol van die amp van die predikant en ook met betrekking tot die liturgie ruimer begin dink. Op hierdie ontwikkelinge in Suid-Afrika en Nederland sal in die laaste deel teruggekom word.

\section{Die musiek}

De volgende historische uitweiding over muziek laat zien dat gezang - al dan niet ondersteund of overgenomen door instrumenten - al ten tijde van de vroeg kerk, maar ook ten tijde van de Reformatie een onlosmakelijk deel was van de liturgie.

Al in het vóór-christelijke, met name joodse, milieu waarbinnen de vroeg-christelijke eredienst is ontstaan, klonk muziek. We weten dat met name in de joodse liturgie vormen van zang bestonden. In de tempel werden door Levieten psalmen gezongen en in de synagoge werd al heel vroeg gebruik gemaakt van (eenvoudige) melodieën bij het lezen van bijbelpassages en het bidden van vaste gebeden (Rouwhorst 2000:31). Zeker is dat er in de eerste eeuwen ook in de kerken gezongen werd. In sommige christelijke (vooral oosterse en dan met name Syrische) kerken lijken hymnen populair te zijn geweest. Ook is goed mogelijk dat bijbelteksten werden gedeclameerd of gereciteerd op een manier die verwant was met de synagogale praktijk en die wij waarschijnlijk als 'zingen' zouden betitelen. Volgens Rouwhorst (2000:33) moet daarbij gebruik gemaakt zijn van een bepaalde reciteertoon of van bepaalde cadensen. Hier is wel belangrijk ons te realiseren dat begrippen als 'zingen', 'lezen' en 'zeggen' in de beeldcultuur van de 21e eeuwse westerse wereld veel duidelijker onderscheiden zijn dan in andere culturen en andere tijden. In de orale traditie van het bijbelse Israel, maar bijvoorbeeld ook in de rhetorica van de klassieke Oudheid, liggen deze begrippen veel dichter bij elkaar en was er voor ritmische en melodische elementen veel meer ruimte. De vroegchristelijke vormen van zang beschouwen wij nu derhalve als uiterst elementair. En hoewel de apostel Paulus in zijn brief aan de Kolossenzen (3:16) de gelovigen oproept om 'psalmen, hymnen en geestelijke liederen' te zingen, duiden ook termen als 'psalmen' en 'hymnen' meer op 'geestelijk loflied' dan op helder van elkaar onderscheiden genres, bepaalde vormen, bepaalde inhoud of herkomst (Zijlstra 2001:13). Het christelijke gebruik van psalmzingen in de liturgie, dat in de derde eeuw ontstond, is vermoedelijk niet rechtstreeks ontleend aan de synagoge, maar heeft zich op eigen wijze en min of meer onafhankelijk van joodse liturgische gebruiken ontwikkeld. Pas in de vierde eeuw raakt het psalmzingen in misvieringen in zwang en krijgt het, getuige Augustinus en andere kerkvaders, populariteit. Naar alle waarschijnlijkheid komt het in verschillende vormen voor: zowel responsoriaal (waarbij het volk één vers als een soort beurtzang herhaalt) als antifonaal (waarbij koor of gemeente in twee groepen gesplitst zijn en afwisselend een psalmvers reciteren).

Wij slaan ook hier grote delen van de geschiedenis over om ons te richten op de ontwikkelingen van muziek (en 
preek) en liturgie gedurende de Reformatie. Vanaf de vierde eeuw werd de kerkmuziek gaandeweg steeds meer door geestelijken en specialisten uitgevoerd. Toen Luther en Calvijn zich er in de zestiende eeuw voor inzetten dat de gemeente zingend deelnam aan de liturgie, was de gemeente passief, luisterde en keek. Gemeentezang klonk bij uitzondering in de liturgie, de rol van gelovigen was minimaal en marginaal. Luther was ervan overtuigd dat er geen beter middel is dan het lied om de gelovige gemeente bij de boodschap van het evangelie te betrekken; zelf schreef hij bijna veertig kerkliederen in de volkstaal. Met in totaal 438 verwijzingen naar de Bijbel hadden deze Lutherliederen een hoog 'Woordgehalte' (Boendermaker 2001:175). Calvijn zette zich in voor de totstandkoming van een complete psalmberijming (verschenen in 1562) met melodieën die het mogelijk maakten dat de gemeenten waarin hij voorging de psalmen in de eigen taal konden zingen. In zijn theologie van muziek is zingen in de kerkdienst van groot belang. Zingen is verkondigen; de gezongen verkondiging heeft voor hem zelfs meer kracht dan de gesproken verkondiging. Is aan een tekst een melodie toegevoegd, dan is de werking van die tekst groter dan wanneer die alleen gesproken wordt (Luth 2001:219)

Het gebruik van het orgel in en rond de eredienst is een punt van discussie geweest in de calvinistische traditie. Die discussie ontstond toen de calvinisten na de Reformatie in bezit kwamen van kerken met orgels. Deze orgels waren eigendom van de overheid en mochten niet verwijderd worden. Orgelspel voor en na de eredienst was gebruikelijk en aanvankelijk de enige vorm van orgelgebruik. In Nederland bepaalde de Synode van Dordrecht in 1574 echter dat het orgelspel na afloop van de dienst moest worden afgeschaft. Daarvoor waren vier argumenten; één ervan was dat orgelspel de preek deed vergeten (Luth 2001:248). Kennelijk was de preek toen al zeer belangrijk en werd ook onderkend dat muziek een grote invloed had. Vóór de eredienst werd van organisten verwacht dat ze psalmen speelden. Dit repertoire was acceptabel en het maakte de gemeenteleden vertrouwd met de psalmmelodieën die in de dienst - nog lange tijd zónder orgelbegeleiding - zouden worden gezongen.

De eredienst in de Gereformeerde traditie is dus gevormd door vóór- en vroeg-christelijke muzikale gebruiken in de eredienst (waarin zang en instrumenten een belangrijke plaats hadden) en door de Reformatie met haar nadruk op het Woord (waarmee níet een onderscheid tussen spreken en zingen wilde zijn gegeven), maar zeker ook door latere ontwikkelingen in Reformatorische kringen, die sterk contextueel bepaald waren. In de loop der eeuwen en dan vooral ná de Reformatie is men prediking, liturgie en muziek in deze traditie als steeds meer gaan zien als onderscheiden van elkaar, terwijl ze voorheen een meer organische eenheid vormden.

Met hierdie historiese oorsig word daar nou gegaan na enkele bestaande teorieë aangaande die verhouding preek, liturgie en musiek.

\section{Bestaande teorieë rakende preek, liturgie en musiek Tom Long}

'n Besonder goeie bydrae kom uit die pen van die homileet Tom Long (2001:42-52; vgl. ook Van der Merwe 2009:165-180) in sy Beyond the worship wars waarin hy die sogenaamde drama van die liturgie behandel. In essensie kom dit vir Long daarop neer dat ' $n$ erediens alreeds dramaties is en nie soseer dramaties gemaak hoef te word nie. Verder het elke soort erediens, byvoorbeeld 'n klassiek-Gereformeerde diensorde, 'n Ekumeniese-diensorde, 'n Misstruktuur en 'n Lof- en Aanbiddingsdiens, alreeds ' $n$ inherente dramatiese struktuur. Die vraag is of die voorganger bewus is van die drama of die storie van die betrokke liturgie waarin hy of sy voorgaan en as sodanig daardie dramatiese struktuur uit die verf kan laat kom. In 'n meer resente boek pas Long (2009) hierdie selfde beginsel toe op die begrafnisliturgie en vra dan juis ook wat die verhaal of storie is wat begrafnisdienste in ons eie dag vertel. Long se uitdaging aan liturge is die vraag of hulle die storie van die erediens kan vertel. Ons kom weer terug op diensordes en die verhale wat hulle vertel. Wat hier verder belangrik is, is om te sien hoedat Long se benadering nou aansluit by die ou liturgiese spreuk lex orandi lex credendi te wete dat die wyse waarop ons (aan)bid heelwat verklap rakende die inhoud van ons geloof, dit is heeltemal toepasbaar op die diensorde as lex orandi wat ' $n$ bepaalde teologie as lex credendi kommunikeer (vgl. ook Small 2003:317). En binne hierdie geheel vind die preek 'n bepaalde plek. Benewens die geheel van die liturgie en die sogenaamde verhaal of drama, is Long van mening dat elke aparte toneel (skene) ook individuele aandag verdien. Hierdie oortuiging van hom beteken dan dat die preek-deel van die diens nie die 'eintlike' deel is, en dat al die ander tonele soos toetrede, tafel en uitsending as bykomende elemente gesien word nie, maar as tonele wat elk waarde in eie reg toevoeg. Long se gedagte van die drama en eenheid van die liturgie is geen onbekende gedagte in die kunste nie.

\section{Integrale visie op liturgie en klank}

Wagner het ten opsigte van die genre van die opera van 'n Gesamtkunstwerk (cf. Moss, 2013) gepraat, te wete dat die elemente in 'n opera: musiek, sang, toneelspel, dekor, kostuums, ensovoorts ' $n$ koherente geheel moet vorm as een sogenaamde gesamentlike kunswerk. Die Suid-Afrikaanse himnoloog Elsabe Kloppers het hierdie konsep ook al diensbaar vir die liturgie gemaak in haar eie navorsing. In 'n artikel getiteld 'Die erediens as omvattende kunswerk' (Kloppers 2003) voer sy veral 'n argument dat al die sintuie gelyktydig aandag kry in die erediens. Hierdie argument geld ook ten opsigte van die verskillende liturgiese elemente en bewegings wat as een geheel saam 'n omvattende kunswerk vorm en dat die preek daardie geheel dien soos al die ander dele dit ook dien en sodoende dien Kloppers se insigte die argument wat ons hier voer.

In Nederlandse liturgisch-rituele studies is de integrale benadering van kerkmuziek in de eredienst ook conceptueel 
verbreed. In The sound of worship (Klomp 2011) wordt muziek bezien als onderdeel van het bredere klankspectrum van de eredienst, wat de aandacht vestigt op het aspect van de 'performance' van het totale liturgische gebeuren. Een overweging op papier is nog geen preek, gedrukte gebedsformules nog geen gebed en bladmuziek nog geen motet of orgelspel. Het gemeenschappelijke van preek, gebed en muziek is dat ze er pas daadwerkelijk zijn wanneer ze tot klinken worden gebracht/worden uitgevoerd.

Geen van deze drie auteurs - Long, Kloppers en Klomp poogt de verschillende elementen van een kunstwerk/ van liturgie of performance op één hoop te vegen of hun onderscheiden eigenschappen te bagatelliseren. $\mathrm{Zij}$ pogen juist de diverse elementen te zien en waarderen als onderdelen van een groter geheel, waardoor zij in een ander licht komen te staan dan wanneer ze als losstaande liturgische elementen worden beschouwd.

\section{Marcel Barnard}

In die boek Als een leerling leren preken (2008:35-49) skryf Marcel Barnard ' $n$ hoofstuk getitel 'Tekst en context/ preek en liturgie'. Barnard kies soos ons vir die teologiese samehang van preek en liturgie en gee dan ook praktiese raad in hierdie verband. Die praktiese vrae wat Barnard vra is: (1) hoe vier die gebou mee? (2) hoe funksioneer die musiek in die erediens? (3) in watter soort diens word die preek gelewer? Prakties toegepas op eredienste in die Nederduitse Gereformeerde Kerk in Suid-Afrika vandag beteken dit dat die gewoonte om byvoorbeeld die musiek-deel van die erediens aan die willekeur van die orrelis of musiekleier oor te laat met min of geen kommunikasie tussen prediker en ander mede-voorgangers in die betrokke liturgie nie, die idee van die samehang en waarde van preek en liturgie ondermyn.

\section{Ordinarium en proprium}

Daar is verskeie woorde wat gebruik kan word vir hierdie konsepte, maar in kort kom dit neer op die oorkoepelende orde (ordinarium) en die verskillende individuele elemente (proprium) in die liturgie (Immink 2011). Julian Müller (1990) verwys na hoekstene en boustene, maar hierdie onderskeid is hier ook belangrik, aangesien die plasing van die hoekstene en boustene bepalend is vir die drama of storie van die liturgie. Die publikasie Woord en fees van Communitas praat al sedert die jare negentig in hierdie verband van sogenaamde vaste- en verskuifbare handelinge in die liturgie. In die nuutste NG Kerk eredienshandleiding uit 2010 word daar nie alleen liturgie nie, maar liturgiese kategese aangebied deurdat die oorsprong en betekenis van individuele elemente soos die votum en wet verduidelik word. Hierdie ontwikkeling is goed en juis handig vir liturge om so die gebruiksmoontlikhede van 'n liturgiese element beter in sig te kry en dan as sodanig aan te wend binne die groter geheel en is presies wat White (2000:169-173) ook aanbeveel vir eredienste binne die Gereformeerde tradisie.

\section{James F. White}

Onder die opskrif 'Pastoral concerns of the service of the Word' argumenteer White (2000:169-173) dat daar besondere uitdagings ten opsigte van liturgie in die Gereformeerde, 'Frontier' en Metodistiese tradisies is, aangesien vele predikante in daardie tradisies dit verkies om hulle eie diensordes vir die erediens saam te stel. As gevolg van die sluimerende gevaar van willekeur in hierdie benadering bied White dan enkele kriteria aan. Eerstens die sentraliteit van die Skrif wat beteken dat nie net een of twee versies gekies en gelees word nie, maar groter dele. Hy breek in dieselfde hoofstuk ook 'n lansie vir die gebruik van die leesrooster wat volgens hom die kans vergroot dat 'n katolieke kanon aangeroer word in die liturgie eerder as 'n plaaslike dominee se kanon van gunstelinge. Tweedens is hy van mening dat daar 'n gevoel van ontwikkeling in 'n diens moet wees waarmee hy bedoel dat die vloei van votum tot seën sinvol moet wees. In noue aansluiting hierby is hy van mening dat die voorgangers die funksie van die onderskeie liturgiese elemente goed moet verstaan om sodoende helderheid te kry oor hoe die onderskeie dele of elemente skakel.

\section{Enkele implikasies}

In essensie kom al hierdie benaderings neer op 'n én-én komplimentêre benadering ten opsigte van preek en liturgie en musiek en dat die belang van ' $n$ sinvolle geheel ten opsigte van die liturgie met 'n sinvolle plek vir die preek binne die groter geheel nie genoegsaam beklemtoon kan word nie. Op die lange duur is nie alleen die preek nie, maar die hele liturgie, en ons wil bysê, veral ook die liedkeuse integraal ten opsigte van die erediensgangers se teologiese dieet en kan 'n groter waardering van so 'n komplimentêre benadering help om teologiese wanvoeding te bekamp.

Die voorafgaande verkenning laat dit ook blyk hoe belangrik dit is dat beide teks en konteks gesamentlik aandag kry in die voorbereiding van die liturgie. Beide teks en konteks is medebepalend vir die storie van die liturgie van 'n betrokke Sondagerediens of ander liturgie. Met konteks word 'n gelaagde geheel bedoel wat insluit die globale, nasionale, plaaslike en gemeentelike konteks, maar juis dan ook die betrokke liturgiese konteks wat sake sal insluit soos die tradisie (Gereformeerd, Luthers, Presbiteriaans), die kerkjaar (in watter seisoen bevind die kerk haar tans), die gemeentelike program (dalk besig met 'n reeks, 40 dae van iets). Dit beteken gelyktydige eksegese van beide teks en konteks om die preek en die vorm van die liturgie te bepaal.

Ten einde 'n argument vir 'n komplimentêre benadering te voer binne die Gereformeerde tradisie sonder om hand in eie identiteitsboesem te steek, sal ons nie besonder ver bring nie. 'n Interessante plek wat vir ons duidelik die NG Kerk se oortuigings in hierdie verband wys, is natuurlik artikel 9 in die Kerkorde en ook die formulier vir die bevestiging van bedienaars van die Woord in die Handleiding vir die erediens. Daardie tekste wys duidelik dat die kerntake van die predikant in die Gereformeerde tradisie gesien word as, 
in die woorde van John Leith, 'preaching, teaching and pastoral care', alhoewel die onlangse uitbreiding daarvan duidelik ook 'die leiding van die eredienste' as ' $n$ afsonderlike taak uitsonder wat' $n$ baie goeie ontwikkeling is. In die formuliere in ons eredienshandleiding hang die liturgies-teologiese onderrok van die NG Kerk egter steeds uit sodat wanneer die gemeente byvoorbeeld opgeroep word om die dienskneg te ontvang aan die einde van die eerste formulier, is die oproep: 'Neem die boodskap wat hy/sy volgens die Heilige Skrif sal verkondig aan, nie as mensewoorde nie, maar soos dit waarlik is, as die Woord van God.' En die tweede formulier noem die verkondiging van die Woord van God onomwonde die 'belangrikste taak' en bevestig dit met die ritueel van die oorhandiging van die Kanselbybel aan die proponent of leraar wat bevestig word. Wanneer ons na die tekste kyk, vra ons onsself dikwels af: 'Hoe kan ons die lied van die Here sing in 'n vreemde (liturgiese) land?'

Daar is alreeds goeie werk gedoen rakende die amp van die predikant en in verskeie Gereformeerde tradisies word die liturgiese bediening van die predikant deesdae ook waardeer as ' $n$ kerntaak en roeping. Onses insiens is hierdie deel van 'n eeueoue ossilasie tussen ' $n$ klem op predikerskap en priesterskap met betrekking tot die amp. Ons het reeds in die historiese oorsig gesien hoedat dit geskuif het tussen priester en prediker. Vanuit die Liturgiegeskiedenis wil dit voorkom asof die klem na die vierde eeu weer geskuif het na priesters en tydens die Reformasie in die Gereformeerde en sommige ander Protestantse tradisies weer na die van prediker. Wat ons bepleit is baie eenvoudig: die amp van priester-predikers met betrekking tot die erediens. Voorgangers se selfverstaan in hierdie verband is krities. Kyk gewoon net hoe Long (2005:18-51) kyk na die meeste metafore vir predikers en die teologie wat daarin opgesluit is. Die meeste predikers sal hulself kan vereenselwig met een van die metafore van boodskapper, storieverteller, pastor of getuie, maar het ons al goed gedink oor 'n metafoor vir onsself as liturge? John Witvliet (1999:1) stel die metafoor gasvrye bemagtigers voor.

Miskien lê 'n voorlopige antwoord daar waar die metafore van Long en Witvliet op 'n sinvolle wyse gekombineer kan word wat dan as sodanig iets verbeeld van die verskeidenheid van liturgiese opdragte van die diens van die Woord, die diens van die gebede, die diens van musiek en die diens van die tafel om enkeles uit te sonder.

\section{Slot}

As outeurs is ons eie verstaan van die verhouding preekliturgie-musiek in die voorbereiding van eredienste én-én: teks (tekskeuse, eksegese, hermeneuse), liturgie (kerkjaar, leesrooster, tipe liturgie) en musiek werk op 'n komplementêre wyse saam om 'n omvattende kunswerk te lewer. Die verhaal wat oorgelewer word week na week is dieselfde verhaal en tog heeltemal anders tegelykertyd.

Sedert 2013 word dosente en studente aan die Universiteit van Pretoria se Fakulteit Teologie aangemoedig om van 'n proeferediens te praat, eerder as 'n proefpreek, maar met die veronderstelling uiteraard dat die proeferediens ' $n$ volledige preek insluit. En vanaf 2011 word Liturgie, Himnologie en Homiletiek sover as moontlik in semestermodules as een geheel gedoseer in fases (liturgies, himnologies, homileties) maar dan juis in kombinasie en ook dat die fases ten dele vervloei. Aan de Protestantse Theologische Universiteit in Amsterdam volgen studenten in hun opleiding tot predikant de cursus 'Voorgaan in de eredienst', waarin zij zich voorbereiden op hun eerste dienst (en dus ook hun eerste preek). In lijn met de holistische visie op de eredienst - en in weerwil van de term 'preekconsent' die in de kerkorde van de Protestantse Kerk in Nederland wordt gebruikt - bezigen enkele docenten in het veld van homiletische en liturgische studies het woord 'voorgangersconsent'. Ons glo hierdie gesprek is belangrik aangesien die keuses wat ons in hierdie verband maak ' $n$ invloed het op hoe die gemeentes waarin ons voorgaan en preek, onthou en hoop.

\section{Erkenning \\ Mededingende belange}

Die outeurs verklaar dat hulle geen finansiële of persoonlike verbintenis het met enige party wat hulle nadelig of voordelig kon beïnvloed het in die skryf van hierdie artikel nie.

\section{Outeursbydrae}

Beide outeurs, C.W. (Universiteit van Petoria) en M.K. (Protestantse Theologische Universiteit) het gelyke aandeel in die skryf van die artikel gehad.

\section{Literatuurverwysings}

Barnard, M., 1998, 'Prediking', in P. Oskamp \& N. Schuman (reds.), De weg van de liturgie: Tradities, achtergronden, praktijk, pp. 210-216, Meinema, Zoetermeer.

Barnard, M., 2008, 'Text en context/preek en liturgie', in H. van der Meulen (red.), Als een leerling leren preken: Preekvoorbereiding stapsgewijs, pp. 34-49, Uitgeverij Boekencentrum, Zoetermeer.

Boendermaker, J.P., 2001, 'De Lutherse traditie', in J. Luth, J. Pasveer \& J. Smelik (reds.), Het kerklied - Een geschiedenis, pp. 165-215, Uitgeverij Boekencentrum, Zoetermeer.

Boon, R., 1970, De joodse wortels van de christelijke eredienst, Mededelingen aflevering 40, Prof. Dr. G. van der Leeuw-Stichting, Amsterdam.

Burger, C.W., 2002, 'Nagmaal in die NG Kerk - Tussen tradisie en vernuwing, deel 2', Nederduitse Gereformeerde Teologiese Tydskrif 43(3/4), 661-669.

Immink, G., 2011, Het heilige gebeurt: Praktijk, theologie en traditie van de protestantse kerkdienst, Meinema, Zoetermeer.

Klomp, M.C.M., 2011, The sound of worship: Liturgical performance by Surinamese Lutherans and Ghanaian Methodists in Amsterdam, Peeters Publishers, Leuven/ Paris/Walpole, MA. (Liturgia Condenda 26).

Kloppers, E., 2003, 'Die erediens as omvattende kunswerk', Nederduits Gereformeerde Teologiese Tydskrif 44(1/2), 80-88.

Long, T.G., 2001, Beyond the worship wars: Building vital and faithful worship, The Alban Institute, Rowman \& Littlefield, Lanham, MD.

Long, T.G., 2005, The witness of preaching, rev. edn, Westminster John Knox Press, Louisville, KY.

Long, T.G., 2009, Accompany them with singing: The Christian funeral, Westminster John Knox Press, Louisville, KY.

Luth, J., 2001, 'De calvinistische traditie', in J. Luth, J. Pasveer \& J. Smelik (reds.), Het kerklied-Een geschiedenis, pp. 217-249, Uitgeverij Boekencentrum, Zoetermeer.

Moss, S., 2013, 'A to Z of Wagner: G is for Gesamtkunstwerk', in Stephen Moss's A to $Z$ of Wagner, viewed 26 November 2014, from http://www.theguardian.com/ music/ musicblog/2013/apr/18/a-z-wagner-gesamtkunstwerk

Müller, J., 1990, Die erediens as fees, NGKB, Pretoria.

Old, H.O., 2002, Worship: Reformed according to Scripture, Westminster John Knox Press, Louisville, KY.

Pellissier, G.M., 1958, Professor G.M. Pellissier: Lewenskets, waardering, laaste preke, oor die erediens, N.G. Kerk-Uitgewers, Kaapstad/Pretoria. 
Rouwhorst, G., 2000, 'De vormgeving van het gezongen eucharistisch gebed in de traditie', in A.C. Vernooij (red.), Liturgie en muzische taal: Het gezongen eucharistisch gebed, pp. 20-47, Gooi \& Sticht, Kampen.

Small, J.D., 2003, 'A church of Word and Sacrament', in L. Vischer (ed.), Christian worship in Reformed churches past and present, pp. 311-323, Eerdmans, Grand Rapids, MI.

Van der Merwe, I.J., 2009, 'Ontdek die bewegings in die erediens', in C.J. Wepener \& I.J. van der Merwe (reds.), Ontdekkings in die erediens, bl. 165-180, Lux Verbi, Bybel-Media, Wellington.

Wepener, C.J., 2002a, 'Nagmaal in die NG Kerk - Tussen tradisie en vernuwing, deel 1', Nederduitse Gereformeerde Teologiese Tydskrif 43(3\&4), 641-651.
Wepener, C.J., 2002b, 'Nagmaal in die NG Kerk - Tussen tradisie en vernuwing, deel 2', Nederduitse Gereformeerde Teologiese Tydskrif 43(3\&4), 652-660.

White, J.F., 2000, Introduction to Christian worship, 3rd edn., revised and expanded, Abingdon, Nashville, TN.

Witvliet, J., 1999, So you have been asked to lead a worship service? Faith Alive Christian Resources, Grand Rapids, MI.

Wolterstorff, N., 1992, 'The Reformed liturgy', in D.K. McKim (ed.), Major themes in the Reformed tradition, Eerdmans, Grand Rapids, MI.

Zijlstra, M., 2001, 'De vroege kerk en de Middeleeuwen', in J. Luth, J. Pasveer \& J. Smelik (eds.), Het kerklied - Een geschiedenis, pp. 13-41, Uitgeverij Boekencentrum, Zoetermee. 